Kong. Res. J. 2(1) : 18-23, 2015

ISSN 2349-2694

Kongunadu Arts and Science College, Coimbatore.

\title{
SYNTHESIS, CHARACTERIZATION AND ANTIBACTERIAL STUDIES ON DIVALENT TRANSITION METAL COMPLEXES OF HYDRAZINE WITH ARYL SUBSTITUTED ACETIC ACIDS
}

\author{
Manimekalai, R*, K. Kalpanadevi, N. Anjutha Prabha and O. Raina \\ Department of Chemistry, Kongunadu Arts and Science College, Coimbatore, Tamil Nadu, India \\ *E-mail: manimekalair@ymail.com
}

\begin{abstract}
Metal phenylacetate Sesquihydrazinate hydrates of the formula $\mathrm{M}(\mathrm{PhAc})_{2} \cdot 1.5 \mathrm{~N}_{2} \mathrm{H}_{4} \cdot \mathrm{H}_{2} \mathrm{O}$ where $\mathrm{M}=\mathrm{Co}, \mathrm{Ni}$ or $\mathrm{Cd}$ and Metal phenoxyacetate Sesquihydrazinate hydrates $\mathrm{M}(\mathrm{PhOAc})_{2} \cdot 1.5 \mathrm{~N}_{2} \mathrm{H}_{4} \cdot \mathrm{H}_{2} \mathrm{O}$ Where $\mathrm{M}=\mathrm{Co}, \mathrm{Ni}, \mathrm{Cd}$ or Mn have been prepared and characterized by analytical, IR spectral and thermal studies. The composition of complexes have been determined by analytical studies. Infrared spectral data indicate that the bidentate bridging by hydrazine molecules and monodentate coordination by carboxylate ions to the cental metal ion. Thermogravimetry (TG) and differential thermal analyses (DTA) in air have been used to study the thermal behaviour of the complexes. The simultaneous TG-DTA curves of all the complexes in air resultedin the formation of respective metal or metal oxide as final residue. These complexes decompose exothermically either in single step or decompose through respective metal carboxylate intermediates. The antibacterial activity of the prepared complexes screened against Staphylococcus aureus, Escherichia coli, Pseudomonas aeruginosa and Proteus mirabilis.
\end{abstract}

Keywords: Phenylacetate Sesquihydrazinate hydrates, phenoxyacetate Sesquihydrazinate hydrates.

\section{INTRODUCTION}

Hydrazine is a versatile ligand and forms a wide variety of complexes with various metal ions. The monodentate and bridging bidentate coordination of the hydrazine molecule on complexation has been well documented in the literature (Braibanti et al., 1968). The emerging interest in these hydrazine complexes is mainly due to their structure and thermal behaviour. Hydrazine carboxylates of the transition metal ions with variety of acids have been reported. These include simple aliphatic monocarboxylic acid (Ravindranathan and Patil, 1983; Sivasankar and Govindrajan, 1994a; Sivasankar and Govindrajan, 1995a; Sivasankar and Govindrajan, 1997; Vikram and Sivasanka, 2007) aliphatic dicarboxylic acids (Gajapathy et al., 1983; Sivasankar and Govindrajan, 1994b; Govindrajan et al., 1995; Yasodhai and Govindrajan, 2000; Sivasankar, 2006) aromatic mono and dicarboxylic acids (Kuppusamy and Govindrajan, 1996; Sivasankar, 2006). Most of these formed as mono, bis-hydrazine or hydrazinium corboxylates and few tris-hydrazine carboxylates are known with aliphatic substituted acetic acid (Kuppusamy and Govindrajan, 1995) and other Inorganic anions (Sivasankar and Govindrajan, 1995; Nicholls et al., 1996). Generally all phenolic derivatives show antibacterial property. Particularly 2,4dichlorophenoxyacetic acid altered envelope properties of the bacteria Escherichia coli, such as hydrophobic index (Blague et al., 2001). This prompted us to make antibacterial study of hydrazinium salt of dichlorophenoxyacetic acid against Escherichia coli.

In this context, we present some new metal hydrazine complexes with aromatic carboxylic acids namely phenylacetic acid and phenoxyacetic acid.

\section{EXPERIMENTAL}

2.1. Preparation of $M(P h A c)_{2} \cdot 1.5 N_{2} H_{4} \cdot H_{2} \mathrm{O}$ where $\mathrm{M}=\mathrm{Co}, \mathrm{Ni}$ or $\mathrm{Cd}$

The Cobalt, Nickel and Cadmium complexes were prepared by the addition of an aqueous solution $(50 \mathrm{ml})$ of hydrazine hydrate $(0.2 \mathrm{ml}, 0.004$ $\mathrm{m})$ and phenylacetic acid $(0.5 \mathrm{~g}, 0.0036 \mathrm{~m})$ to the corresponding aqueous solution $(50 \mathrm{ml})$ of metal nitrate hydrates $\left(\mathrm{Co}\left(\mathrm{NO}_{3}\right)_{2} .6 \mathrm{H}_{2} \mathrm{O}, 0.5 \mathrm{~g}, 0.0017 \mathrm{~m}\right.$, $\mathrm{Ni}\left(\mathrm{NO}_{3}\right)_{2} .6 \mathrm{H}_{2} \mathrm{O}, 0.5 \mathrm{~g}, 0.0017 \mathrm{~m}, \mathrm{Cd}\left(\mathrm{NO}_{3}\right)_{2} .4 \mathrm{H}_{2} \mathrm{O}, 0.5 \mathrm{~g}$, $0.0016 \mathrm{~m}$ ). The mixture was stirred well to get a clear solution. This solution was concentrated on a water bath to $20 \mathrm{ml}$ and it was kept for complexation. After 15 minutes complex was formed. It was filtered and washed by using water, alcohol and diethyl ether and air dried.

\subsection{Preparation of $\mathrm{Mn}(\mathrm{PhAc})_{2} \cdot 1.5 \mathrm{~N}_{2} \mathrm{H}_{4} \cdot \mathrm{H}_{2} \mathrm{O}$}

The manganese complex was also prepared by the same procedure with aqueous solution $(50 \mathrm{ml})$ of phenylacetic acid $(0.5 \mathrm{~g}, 0.0036 \mathrm{~m})$, hydrazine 
hydrate $(0.4 \mathrm{ml}, 0.008 \mathrm{~m})$ and aqueous solution of manganese acetate hydrate $(0.5 \mathrm{~g}, 0.002 \mathrm{~m})$.

2.3. Preparation of $\mathrm{M}(\mathrm{PhOAc}) .1 .5 \mathrm{~N}_{242}^{\mathrm{H} . \mathrm{HO}}$ Where $\mathrm{M}=\mathrm{Co}, \mathrm{Ni}, \mathrm{Cd}$ or $\mathrm{Mn}$

The same procedure was followed with aqueous solution of Phenoxyacetic acid $(0.5 \mathrm{~g}$, $0.0032 \mathrm{~m})$, hydrazine hydrate $(0.2 \mathrm{ml}, 0.004 \mathrm{~m})$ and metal nitrate hydrates $(0.5 \mathrm{~g}, 0.0017 \mathrm{~m})$ (or) Manganese acetate hydrate $(0.5 \mathrm{~g}, 0.002 \mathrm{~m})$.

\subsection{Quantitative methods}

The hydrazine content in the complexes was determined by titration using $\mathrm{KIO}_{3}$ as the titrant (Von Burg and Stout, 1991). The percentage of metals in the complexes was estimated by the standard methods given in the Vogel's textbook (Von Burg and Stout, 1991).

\subsection{Physico-chemical techniques}

\subsubsection{Infrared spectrum}

The infrared spectrum of the solid precursor sample was recorded by the $\mathrm{KBr}$ disc technique using a Perkin Elmer 597/1650 spectrophotometer.

\subsubsection{Thermal analysis}

The simultaneous TG-DTA experiment was carried out in Shimadzu DT40, Stanton 781 and STA 1500 thermal analyzer. Thermal analysis was carried out in air at the heating rate of $10^{\circ} \mathrm{C}$ per minute using 5-10 mg of the sample. Platinum cups were used as sample holders and alumina as reference. The temperature range was ambient to $700^{\circ} \mathrm{C}$.

\subsubsection{Biological assay}

The antibacterial activities of the prepared complexes were determined by the disc diffusion method. The bacteria were cultured in nutrient agar medium and used as inoculum for the study. The antibacterial activity of the synthesized compounds of $25 \mu \mathrm{g}, 50 \mu \mathrm{g}, 100 \mu \mathrm{g}$ and $200 \mu \mathrm{g}$ concentrations were tested against Staphylococcus aureus, Escherichia coli, Pseudomonas aeruginosa and Proteus mirabilis. The inhibition zones were calculated and recorded.

\section{RESULTS AND DISCUSSION}

\subsection{Chemical formula determination of the complexes}

The chemical formula $\left[\mathrm{M}(\mathrm{PhAc})_{2} \cdot 1 \cdot 5 \mathrm{~N}_{2} \mathrm{H}_{4} \cdot \mathrm{H}_{2} \mathrm{O}\right.$ $(\mathrm{M}=\mathrm{Ni}, \mathrm{Co}, \mathrm{Mn}, \mathrm{Cd})$ and $\mathrm{M}(\mathrm{PhOAc})_{2} \cdot 1 \cdot 5 \mathrm{~N}_{2} \mathrm{H}_{4} \cdot \mathrm{H}_{2} \mathrm{O}(\mathrm{M}=$ $\mathrm{Co}, \mathrm{Ni}, \mathrm{Cd}, \mathrm{Mn}$ ) has been assigned to the prepared complexes, based on the observed and calculated percentage of hydrazine and metals, which are found to match closely with the calculated values (Table 1).
Table 1. Compositional analysis data of the prepared complexes.

\begin{tabular}{|c|c|c|c|c|c|}
\hline \multirow[b]{2}{*}{ Compound } & \multirow{2}{*}{$\begin{array}{l}\text { Molecular } \\
\text { weight } \\
\text { (gm) }\end{array}$} & \multicolumn{2}{|c|}{$\begin{array}{c}\text { Hydrazine } \\
(\%)\end{array}$} & \multicolumn{2}{|c|}{ Metal (\%) } \\
\hline & & $\begin{array}{l}\text { Obsd } \\
\text { value }\end{array}$ & $\begin{array}{l}\text { Calcd } \\
\text { value }\end{array}$ & $\begin{array}{l}\text { Obsd } \\
\text { value }\end{array}$ & $\begin{array}{l}\text { Calcd } \\
\text { value }\end{array}$ \\
\hline $\begin{array}{l}\mathrm{Co}(\mathrm{PhAc})_{2} .1 .5 \\
\mathrm{~N}_{2} \mathrm{H}_{4} \cdot \mathrm{H}_{2} \mathrm{O} \\
\mathrm{Ni}(\mathrm{PhAc})_{2.1 .5}\end{array}$ & 397.35 & 12.25 & 12.16 & 14.55 & 14.92 \\
\hline $\mathrm{N}_{2} \mathrm{H}_{4} . \mathrm{H}_{2} \mathrm{O}$ & 395.08 & 12.66 & 12.17 & 14.50 & 14.86 \\
\hline $\begin{array}{l}\mathrm{Cd}(\mathrm{PhAc})_{2.1 .5} \\
\mathrm{~N}_{2} \mathrm{H}_{4} \cdot \mathrm{H}_{2} \mathrm{O}\end{array}$ & 449.31 & 9.93 & 10.70 & 26.2 & 25.24 \\
\hline $\begin{array}{l}\mathrm{Mn}(\mathrm{PhAc})_{2.1 .5} \\
\mathrm{~N}_{2} \mathrm{H}_{4} \cdot \mathrm{H}_{2} \mathrm{O}\end{array}$ & 391.3 & 12.25 & 12.28 & 14.00 & 14.03 \\
\hline $\begin{array}{l}\mathrm{Co}(\mathrm{PhOAc})_{2.1 .5} \\
\mathrm{~N}_{2} \mathrm{H}_{4} \cdot \mathrm{H}_{2} \mathrm{O}\end{array}$ & 427.39 & 10.09 & 11.25 & 13.00 & 13.80 \\
\hline $\begin{array}{l}\mathrm{Ni}(\mathrm{PhOAc})_{2.1 .5} \\
\mathrm{~N}_{2} \mathrm{H}_{4} \cdot \mathrm{H}_{2} \mathrm{O}\end{array}$ & 427.1 & 10.65 & 11.25 & 13.00 & 13.74 \\
\hline $\begin{array}{l}\mathrm{Cd}(\mathrm{PhOAc})_{2.1 .5} \\
\mathrm{~N}_{2} \mathrm{H}_{4} \cdot \mathrm{H}_{2} \mathrm{O}\end{array}$ & 481.33 & 9.40 & 9.99 & 24.46 & 23.46 \\
\hline $\begin{array}{l}\mathrm{Mn}(\mathrm{PhOAc})_{2} \cdot 1 . \\
5 \mathrm{~N}_{2} \mathrm{H}_{4} \cdot \mathrm{H}_{2} \mathrm{O}\end{array}$ & 423.32 & 10.65 & 11.36 & 12.00 & 12.79 \\
\hline
\end{tabular}

\subsubsection{PhOAc-Phenoxyacetate}

These are in good agreement with proposed formulae of the complexes.

\subsection{FT-IR spectral analysis}

The hydrated derivatives displayed a broad band in the region $3625-3282 \mathrm{~cm}^{-1}$ due to $\mathrm{O}-\mathrm{H}$ stretching shows the presence of water molecule. The absorption band in the region 3246-3224 $\mathrm{cm}^{-}$ ${ }^{1}$.This is due to the $\mathrm{N}-\mathrm{H}$ stretching frequency of $\mathrm{N}_{2} \mathrm{H}_{4}$. The complexes show asymmetric and symmetric stretching frequencies of $\mathrm{COO}^{-}$in the region 1610$156 \mathrm{~cm}^{-1}$ and $1392-1338 \mathrm{~cm}^{-1}$ respectively. The $\Delta \gamma\left(\gamma_{\text {asym }} \gamma_{\text {sym }}\right)$ of COO- in range $>222 \mathrm{~cm}^{-1}$ confirms the monodendate coordination of carboxylate anion. In the complexes, the N-N stretching is seen in the range 983-943 $\mathrm{cm}^{-1}$ confirming the bridging bidentate coordination of hydrazine (Sivasankar and Govindrajan, 1996). The IR spectra of the prepared complexes are displayed in Fig. 1- 8.

Table 2. FT-IR spectral data of the prepared complexes.

\begin{tabular}{|c|c|c|c|c|c|c|}
\hline Compound & $\gamma_{(0-\mathrm{H})}$ & $\gamma_{(\mathrm{N}-\mathrm{H})}$ & $\gamma_{\text {asy}(0 c o)}$ & $\gamma_{\text {sym(oco) }}$ & $\Delta \gamma$ & $\gamma_{(\mathrm{N}-\mathrm{N})}$ \\
\hline $\begin{array}{l}\mathrm{Co}(\mathrm{PhAc})_{2} \cdot 1 . \\
5 \mathrm{~N}_{2} \mathrm{H}_{4} \cdot \mathrm{H}_{2} \mathrm{O}\end{array}$ & 3294 & 3226 & 1606 & 1382 & 224 & 970 \\
\hline $\begin{array}{l}\mathrm{Ni}(\mathrm{PhAc})_{2} .1 . \\
5 \mathrm{~N}_{2} \mathrm{H}_{4} \cdot \mathrm{H}_{2} \mathrm{O}\end{array}$ & 3292 & 3224 & 1604 & 1382 & 222 & 975 \\
\hline $\begin{array}{l}\mathrm{Cd}(\mathrm{PhAc})_{2} .1 . \\
5 \mathrm{~N}_{2} \mathrm{H}_{4} \cdot \mathrm{H}_{2} \mathrm{O}\end{array}$ & 3303 & 3246 & 1610 & 1384 & 226 & 958 \\
\hline $\begin{array}{l}\mathrm{Mn}(\mathrm{PhAc})_{2.1} .1 \\
.5 \mathrm{~N}_{2} \mathrm{H}_{4} \cdot \mathrm{H}_{2} \mathrm{O}\end{array}$ & 3625 & - & 1566 & 1392 & - & 943 \\
\hline $\begin{array}{l}\mathrm{Co}(\mathrm{PhOAc})_{2} . \\
1.5 \mathrm{~N}_{2} \mathrm{H}_{4} \cdot \mathrm{H}_{2} \mathrm{O}\end{array}$ & 3282 & 3228 & 1598 & 1342 & 256 & 948 \\
\hline $\begin{array}{l}\mathrm{Ni}\left(\mathrm{PhOAc}_{2} .\right. \\
1.5 \mathrm{~N}_{2} \mathrm{H}_{4} \cdot \mathrm{H}_{2} \mathrm{O}\end{array}$ & 3282 & 3244 & 1585 & 1344 & 247 & 983 \\
\hline $\begin{array}{l}\mathrm{Cd}(\mathrm{PhOAc})_{2} \text {. } \\
1.5 \mathrm{~N}_{2} \mathrm{H}_{4} \cdot \mathrm{H}_{2} \mathrm{O}\end{array}$ & 3326 & 3242 & 1608 & 1346 & 262 & 968 \\
\hline $\mathrm{Mn}(\mathrm{PhOAc})_{2}$ & 3330 & 3240 & 1583 & 1338 & 245 & 964 \\
\hline
\end{tabular}

$\Delta \gamma=\left(\gamma_{\text {asy(OCO) }}-\gamma_{\text {sym(oco) }}\right)$ 


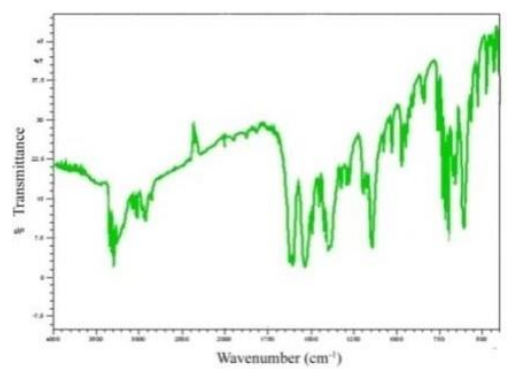

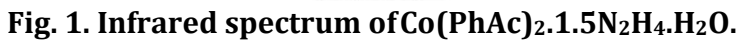

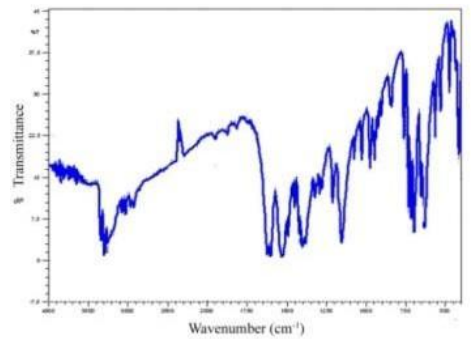

Fig. 2. Infrared spectrum of Ni(PhAc) $)_{2} \cdot 1 \cdot 5 \mathrm{~N}_{2} \mathrm{H}_{4} \cdot \mathrm{H}_{2} \mathrm{O}$.

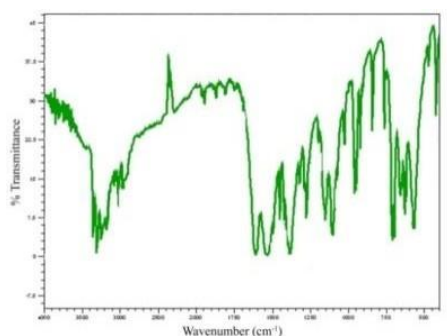

Fig. 3. Infrared spectrum of $\mathrm{Cd}(\mathrm{PhAc}) 2.1 .5 \mathrm{~N}_{2} \mathrm{H}_{4} \cdot \mathrm{H}_{2} \mathrm{O}$

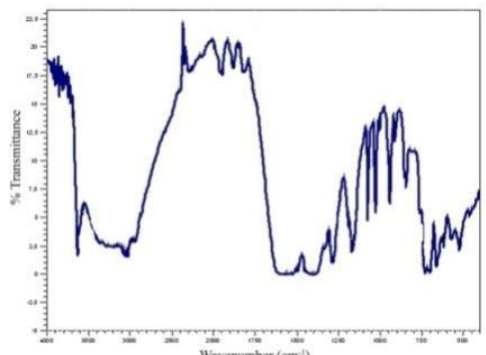

Fig. 4. Infrared spectrum of $\mathrm{Mn}(\mathrm{PhAc})_{2} .1 .5 \mathrm{~N}_{2} \mathrm{H}_{4} \cdot \mathrm{H}_{2} \mathrm{O}$

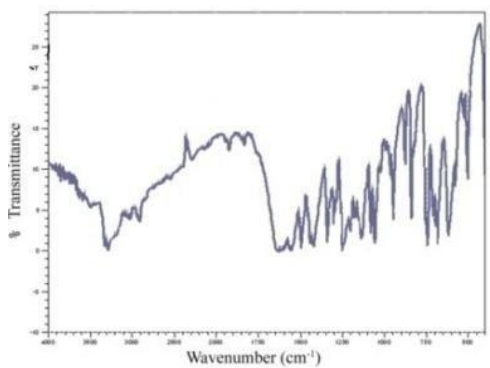

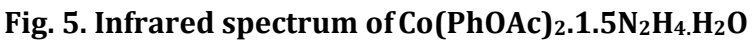

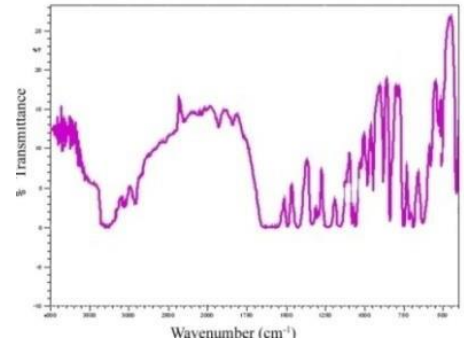

Fig. 6. Infrared spectrum of Ni(PhOAc) $)_{2} .1 .5 \mathrm{~N}_{2} \mathrm{H}_{4} \cdot \mathrm{H}_{2} \mathrm{O}$

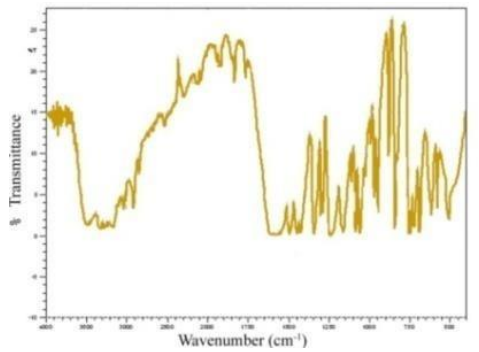

Fig.7. Infrared spectrum of Cd(PhOAc) $)_{2} .1 .5 \mathrm{~N}_{2} \mathrm{H}_{4} . \mathrm{H}_{2} \mathrm{O}$

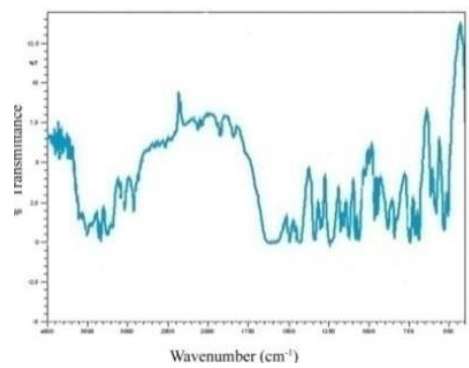

Fig. 8. Infrared spectrum of $\mathrm{Mn}(\mathrm{PhOAc})_{2} .1 .5 \mathrm{~N}_{2} \mathrm{H}_{4} \cdot \mathrm{H}_{2} \mathrm{O}$

Table 3. The thermal decomposition pattern of some complexes are given.

\begin{tabular}{|c|c|c|c|c|c|}
\hline \multirow{2}{*}{ Compound } & \multirow{2}{*}{$\begin{array}{l}\text { DTA -Peak } \\
\text { Temp } /{ }^{\circ} \mathrm{C}\end{array}$} & \multirow{2}{*}{$\begin{array}{c}\text { TG - Temp } \\
\text { Rang/ }{ }^{\circ} \mathrm{C}\end{array}$} & \multicolumn{2}{|c|}{ Mass Loss \% } & \multirow{2}{*}{ Decomposition product } \\
\hline & & & Found & Calcd & \\
\hline \multirow[t]{2}{*}{$\mathrm{Co}(\mathrm{PhAc})_{2} \cdot 1.5 \mathrm{~N}_{2} \mathrm{H}_{4} \cdot \mathrm{H}_{2} \mathrm{O}$} & $220(+)$ & $175-245$ & 14.55 & 16.71 & $\mathrm{Co}(\mathrm{PhAc})_{2}$ \\
\hline & $440(+)$ & $245-500$ & 80.92 & 81.03 & $\mathrm{CoO}$ \\
\hline \multirow{3}{*}{$\mathrm{Cd}(\mathrm{PhOAc})_{2} \cdot 1 \cdot 5 \mathrm{~N}_{2} \mathrm{H}_{4} \cdot \mathrm{H}_{2} \mathrm{O}$} & $140(-)$ & $105-160$ & 3.6 & 3.7 & 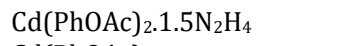 \\
\hline & $205(-)$ & $170-230$ & 12 & 13.72 & $\mathrm{Cd}(\mathrm{PhOAc})_{2}$ \\
\hline & $520(+)$ & $400-580$ & 73.46 & 73.21 & $\mathrm{CdO}$ \\
\hline \multirow[t]{2}{*}{$\mathrm{Ni}(\mathrm{PhAc})_{2} \cdot 1 \cdot 5 \mathrm{~N}_{2} \mathrm{H}_{4} \cdot \mathrm{H}_{2} \mathrm{O}$} & $230(+)$ & $195-250$ & 16.37 & 16.72 & $\mathrm{Ni}(\mathrm{PhAc})_{2}$ \\
\hline & $465(+)$ & $370-480$ & 83.32 & 81.08 & $\mathrm{NiO}$ \\
\hline
\end{tabular}




\subsection{Thermal analysis}

\section{4. $\mathrm{Co}(\mathrm{PhAc})_{2} \cdot 1.5 \mathrm{~N}_{2} \mathrm{H}_{4} \cdot \mathrm{H}_{2} \mathrm{O}$}

This complex undergoes two step decomposition. The TG curve shows $14 \%$ mass loss in the temperature range $175-245^{\circ} \mathrm{C}$ which coincides with the calculated mass loss for the formation of $\mathrm{Co}(\mathrm{PhAc})_{2}$ with loss of hydrazine and water molecule. The higher temperature decomposition indicates that coordinated water molecule. This intermediate further decomposes in the temperature range $245-500^{\circ} \mathrm{C}$ to give $\mathrm{CoO}$, as the final product. DTA shows exotherm corresponding to the above two stages at 220 and $440^{\circ} \mathrm{C}$, respectively. The TGDTA pattern of this complex is given in Fig.9.

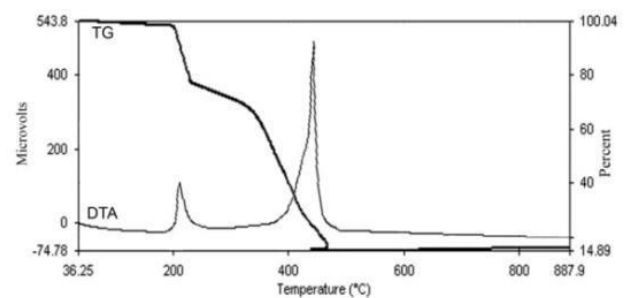

Fig. 9. $\mathrm{Co}(\mathrm{PhAc})_{2} .1 .5 \mathrm{~N}_{2} \mathrm{H}_{4} \cdot \mathrm{H}_{2} \mathrm{O}$

\section{5. $\mathrm{Cd}(\mathrm{PhOAc})_{2.1} .5 \mathrm{~N}_{2} \mathrm{H}_{4} \cdot \mathrm{H}_{2} \mathrm{O}$}

This DTA curves reveal three peaks corresponding to three step decomposition of the complex as shown by TG. The first endothermic peak at $140{ }^{\circ} \mathrm{C}$ is assigned to the loss of molecule of water. The second step corresponds to the decomposition of the intermediate, $\mathrm{Cd}(\mathrm{PhOAc})_{2} \cdot 1.5 \mathrm{~N}_{2} \mathrm{H}_{4}$ to yield $\mathrm{Cd}(\mathrm{PhOAc})_{2}$ which is observed as an endotherm at $205^{\circ} \mathrm{C}$, in DTA. The $\mathrm{Cd}(\mathrm{PhOAc})_{2}$ further decomposes exothermically at $520^{\circ} \mathrm{C}$ in the final step to form CdO as the end product. The thermogram of the complex is given in Fig. 10.

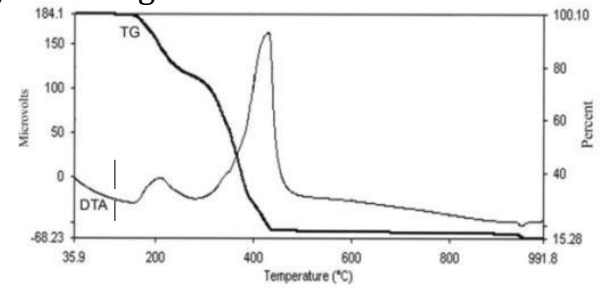

Fig. 10. $\mathrm{Cd}(\mathrm{PhOAc})_{2} \cdot 1.5 \mathrm{~N}_{2} \mathrm{H}_{4} \cdot \mathrm{H}_{2} \mathrm{O}$

\subsection{Ni(PhAC) ${ }_{2} .1 .5 \mathrm{~N} \mathrm{H.H} \mathrm{O}_{242}$}

This complex undergoes two step decomposition. The TG curve shows $16 \%$ mass loss in the temperature range $195-250^{\circ} \mathrm{C}$ which coincides with the calculated mass loss for the formation of $\mathrm{Ni}(\mathrm{PhAc})_{2}$ as an intermediate. This intermediate further decomposes in the temperature range 370$480^{\circ} \mathrm{C}$ to give $\mathrm{NiO}$, as the final product. DTA shows exotherm corresponding to the above two stages at
230 and $465^{\circ} \mathrm{C}$, respectively. The TG-DTA pattern of this complex is given in Fig. 11.

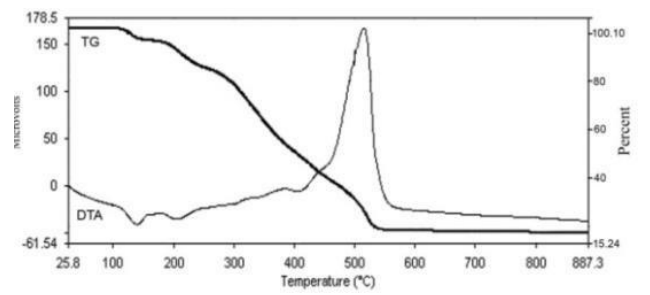

Fig. 11. $\mathrm{Ni}(\mathrm{PhAc})_{2} .1 .5 \mathrm{~N}_{2} \mathrm{H}_{4} \cdot \mathrm{H}_{2} \mathrm{O}$

\subsection{Coordination geometry}

The analytical and physico chemical studies suggest that, in these complexes ,the hydrazine molecules are present as a bidentate bridging ligand. The phenylacetate and phenoxyacetate ions are seen to present as a monodentate ligand (Figs. 12 and 13) as evidented from IR spectra. From TG-DTA analysis we confirmed that water molecule is present as a coordinated one. The complexes are isolated only as a polycrystalline powders. Hence, without crystal structure, it is very difficult to predict the environment of the metal in the complexes. Sixcoordination has been tentatively proposed for all the complexes with octahedral stereochemistry. The insoluble nature of these complexes conforms to the polymeric structure.

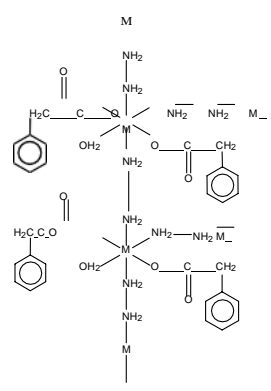

Fig. 12. Polymeric structure $\mathrm{M}(\mathrm{PhAc})_{2} \cdot 1.5 \mathrm{~N}_{2} \mathrm{H}_{4} \cdot \mathrm{H}_{2} \mathrm{O}$ where $\mathrm{M}=\mathrm{Co}, \mathrm{Ni}, \mathrm{Cd}$ and $\mathrm{Mn}$

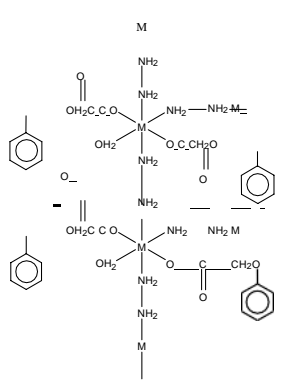

Fig. 13. Polymeric structure $\mathrm{M}(\mathrm{PhOAc})_{2} \cdot 1.5 \mathrm{~N}_{2} \mathrm{H}_{4} \cdot \mathrm{H}_{2} \mathrm{O}$ where $\mathrm{M}=\mathrm{Co}, \mathrm{Ni}, \mathrm{Cd}$ and $\mathrm{Mn}$

\subsection{Antibacterial studies}


The complexes of phenylacetic and phenoxyacetic acid have been screened to evaluate their antibacterial activities against (A) Staphylococcus aureus, (B) Escherichia coli, (C) Pseudomonas aeruginosa, (D) Proteus mirabilis, respectively at two different concentrations (Fig. 14). The radius of the zone of inhibition was measured in millimeter. Cefepimetazobactum were used as a standard control and is tabulated as follows.

Table 4. Antibacterial activities of the complexes are given. (the test solutions were prepared in dil $\mathrm{HCl}$.

\begin{tabular}{|c|c|c|c|c|c|c|c|c|c|}
\hline \multirow{3}{*}{$\begin{array}{l}\mathbf{S} . \\
\mathbf{N} \\
\mathbf{o}\end{array}$} & \multirow{3}{*}{ Compound } & \multicolumn{8}{|c|}{ Diameter of inhibition zone ( $\mathrm{mm}$ ) } \\
\hline & & \multicolumn{2}{|c|}{ S. aureus } & \multicolumn{2}{|c|}{ E.coli } & \multicolumn{2}{|c|}{$\begin{array}{c}P . \\
\text { aeruginosa }\end{array}$} & \multicolumn{2}{|c|}{ P. mirabilis } \\
\hline & & 50 & 100 & 50 & 100 & 50 & 100 & 50 & 100 \\
\hline 1 & $\begin{array}{l}\mathrm{o}(\mathrm{PhAc})_{2} . \\
1.5 \mathrm{~N}_{2} \mathrm{H}_{4} \cdot \mathrm{H}_{2} \mathrm{O}\end{array}$ & 10 & 18 & - & - & - & 18 & - & 17 \\
\hline 2 & $\begin{array}{l}\mathrm{Ni} / \mathrm{HhAc})_{2 .} . \\
1.5 \mathrm{~N}_{2} \mathrm{H}_{4} \cdot \mathrm{H}_{2} \mathrm{O}\end{array}$ & - & - & 12 & 12 & - & - & - & - \\
\hline 3 & $\begin{array}{l}\mathrm{Cd}(\mathrm{PhAc})_{2} . \\
1.5 \mathrm{~N}_{2} \mathrm{H}_{4} \cdot \mathrm{H}_{2} \mathrm{O}\end{array}$ & - & - & - & - & - & - & - & 12 \\
\hline 4 & $\begin{array}{l}\mathrm{Mn}(\mathrm{PhAc})_{2} . \\
1.5 \mathrm{~N}_{2} \mathrm{H}_{4} \cdot \mathrm{H}_{2} \mathrm{O}\end{array}$ & - & 15 & - & 15 & - & - & - & - \\
\hline 5 & $\begin{array}{l}\mathrm{Co}(\mathrm{PhOAc})_{2} . \\
1.5 \mathrm{~N}_{2} \mathrm{H}_{4} \cdot \mathrm{H}_{2} \mathrm{O}\end{array}$ & - & 17 & 8 & 18 & - & 20 & - & 14 \\
\hline 6 & $\begin{array}{l}\mathrm{Ni}\left(\mathrm{PhOAc}_{2} .\right. \\
1.5 \mathrm{~N}_{2} \mathrm{H}_{4} \cdot \mathrm{H}_{2} \mathrm{O}\end{array}$ & - & - & - & - & - & 8 & - & 10 \\
\hline 7 & $\begin{array}{l}\mathrm{Cd}(\mathrm{PhOAc})_{2} . \\
1.5 \mathrm{~N}_{2} \mathrm{H}_{4} \cdot \mathrm{H}_{2} \mathrm{O}\end{array}$ & - & 7 & - & 8 & - & 6 & 12 & 12 \\
\hline 8 & $\begin{array}{l}\mathrm{Mn}(\mathrm{PhOAc})_{2} . \\
1.5 \mathrm{~N}_{2} \mathrm{H}_{4} \cdot \mathrm{H}_{2} \mathrm{O}\end{array}$ & - & - & - & - & - & - & - & - \\
\hline & $\begin{array}{l}\text { Sefepimetazob } \\
\text { a ctum }\end{array}$ & & 24 & & 24 & & 20 & & 20 \\
\hline
\end{tabular}

From the result, it has been observed that there is a concentration dependent percentage inhibition in the tested compounds. The activities of the complexes have been compared with the activity of standard antibiotics (Cefepimetazobactum) and it has been found that all the complexes showed good activities but compound $\mathrm{Mn}(\mathrm{PhOAc})_{2} \cdot 1 \cdot 5 \cdot \mathrm{N}_{2} \mathrm{H}_{4} \cdot \mathrm{H}_{2} \mathrm{O}$ has no activity against all the four microorganisms.

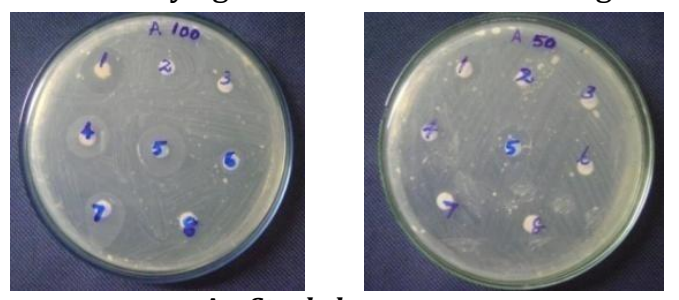

A - Staphylococcus aureus
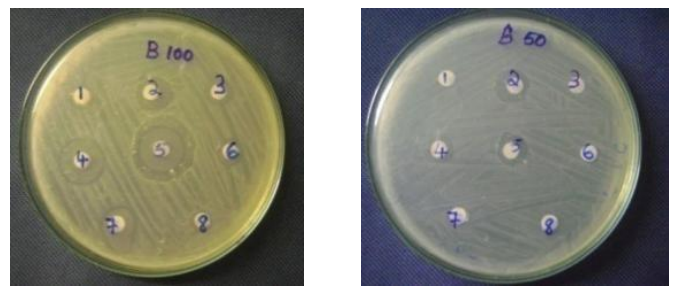

B - Escherichia coli

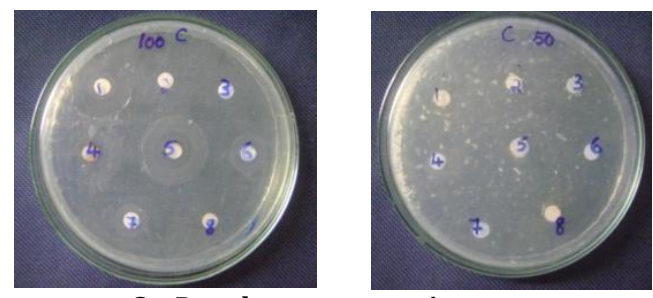

C - Pseudomonas aeruginosa

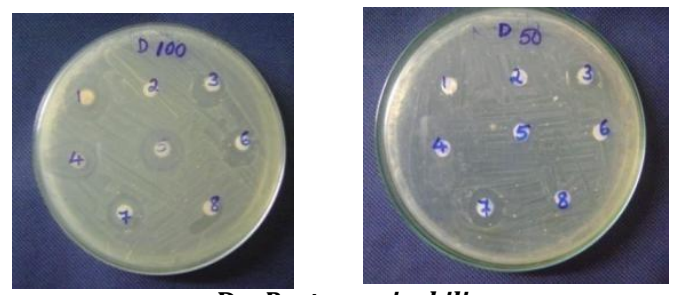

D - Proteus mirabilis

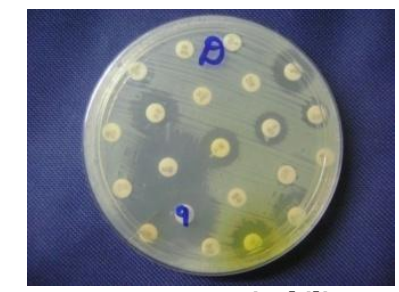

D - Proteus mirabilis

9 - Cefepimetazobactum (Standard)

Fig. 14. Screening for the antibacterial activity at $100 \%$ and $50 \%$ concentration

From the Table 3.4, it can be seen that the compounds $\mathrm{Co}(\mathrm{PhoAc})_{2} \cdot 1.5 \mathrm{~N}_{2} \mathrm{H}_{4} \cdot \mathrm{H}_{2} \mathrm{O}$ showed remarkable activity against Pseudomonas aeruginosa, and Escherichia coli. Compound $\mathrm{Co}(\mathrm{PhAc})-$ $2 \cdot 1.5 \mathrm{~N}_{2} \mathrm{H}_{4} \cdot \mathrm{H}_{2} \mathrm{O}$ showed remarkable activity against Pseudomonas aeruginosa, and Staphylococcus aureus.

The results suggest that the antibacterial activity of complexes prepared from both phenylacetic acid phenoxyacetic acid are almost same. This may be due to structural relaitivity between them.

\section{CONCLUSION}

Transition metal hydrazine complexes of the type $\mathrm{M}(\mathrm{PhAc})_{2} \cdot \mathrm{l} .5 \mathrm{~N}_{2} \mathrm{H}_{4} \cdot \mathrm{H}_{2} \mathrm{O}$ where $\mathrm{M}=\mathrm{Co}, \mathrm{Ni}$, Cd (or) $\mathrm{Mn}, \mathrm{M}(\mathrm{PhOAc})_{2} \cdot 1.5 \mathrm{~N}_{2} \mathrm{H}_{4} \cdot \mathrm{H}_{2} \mathrm{O}$ where $\mathrm{M}=\mathrm{Co}, \mathrm{Ni}, \mathrm{Cd}$ (or) $\mathrm{Mn}$ were prepared in aqueous medium by using respective metal nitrate hydrate or metal acetate hydrate, hydrazine hydrate and phenylacetic acid or phenoxyacetic acid. Among the hydrazine derivatives, sesquihydrazinates are unique complexes, and also it is appropriate to mention here that these types of complexes are separated only with these acids except cadmium oxalate sesquihydrazinate ${ }^{126}$.

The prepared complexes were characterized by IR and thermogravimetric analysis. The antibacterial 
activity of the complexes against Staphylococcus aureus, Escherichia coli, Pseudomonas aeruginosa and Proteus mirabilis were also carried out.

The IR spectral data indicates that the binding of hydrazine to a metal ion is a bidentate fashion. Carboxylate ligands are monodentatively coordinated to the central metal ion. The broad peak around $3625-3282 \mathrm{~cm}^{-1}$ indicates the presence of water molecule. The prepared complexes undergo two or three step decomposition to form metal oxide as the final product. The higher temperature dehydration indicates that the presence of water molecule as coordinated one.

The antibacterial screening shows that $\mathrm{Co}(\mathrm{PhOAc})_{2} .1 .5 \mathrm{~N}_{2} \mathrm{H}_{4} \cdot \mathrm{H}_{2} \mathrm{O}, \mathrm{Cd}(\mathrm{PhOAc})_{2} .1 .5 \mathrm{~N}_{2} \mathrm{H}_{4} \cdot \mathrm{H}_{2} \mathrm{O}$ are active against Staphylococcus aureus, Escherichia coli, Pseudomonas aeruginosa and Proteus mirabilis. $\mathrm{Co}(\mathrm{PhAc})_{2} .1 .5 \mathrm{~N}_{2} \mathrm{H}_{4} \cdot \mathrm{H}_{2} \mathrm{O}$ active against Staphylococcus aureus, Pseudomonas aeruginosa and Proteus mirabilis. $\mathrm{Ni}(\mathrm{PhOAc})_{2} \cdot 1.5 \mathrm{~N}_{2} \mathrm{H}_{4} \cdot \mathrm{H}_{2} \mathrm{O}$ active against Pseudomonas aeruginosa and Proteus mirabilis. $\mathrm{Mn}(\mathrm{PhAc})_{2} \cdot 1.5 \mathrm{~N}_{2} \mathrm{H}_{4} \cdot \mathrm{H}_{2} \mathrm{O}$ active against Staphylococcus aureus, and Escherichia coli. $\mathrm{Ni}(\mathrm{PhAc})_{2} \cdot \mathrm{l} .5 \mathrm{~N}_{2} \mathrm{H}_{4} \cdot \mathrm{H}_{2} \mathrm{O}$ and $\mathrm{Cd}(\mathrm{PhAc})_{2} \cdot \mathrm{l} \cdot 5 \mathrm{~N}_{2} \mathrm{H}_{4} \cdot \mathrm{H}_{2} \mathrm{O}$ shows active against only Escherichia coli and Proteus mirabilis respectively. $\mathrm{Mn}(\mathrm{PhOAc})_{2} \cdot \mathrm{l} .5 \mathrm{~N}_{2} \mathrm{H}_{4} \cdot \mathrm{H}_{2} \mathrm{O}$ does not show any antibacterial activity.

\section{REFERENCES}

Balague, C., N. Stirtz, R. Duffard and A.M. Evangelista de Duffard, (2001). Effect of 2, 4dichlorophenoxyacetic acid herbicide in Escherichia Coli growth chemical composition and cellular envelope. Environ. Toxicol. 16: 4353.

Braibanti, A., F. Dallavalle, M.A. Pellinghelli and E. Laporti, (1968). The nitrogen-nitrogen stretching band in hydrazine derivatives and complexes. Inorg. Chem. 7: 1430-1433.

Gajapathy, D., S. Govindrajan, K.C. Patil and H. Monohar, (1983). Synthesis, characterisation and thermal properties of Hydrazinium metal oxalate hydrates. Crystal and molecular structure of hydrazinium Copper oxalate monohydrate. Polyhedron 2: 865-873.

Govindrajan, S., S.U. Nasrin Banu, N. Saravanan and B.N. Sivasankar, (1995). Bis-Hydrazine metal maleates and fumarates: Preparation, spectral and thermal studies. Proc. Indian. Acad. Sci. (Chem. Sci.) 107: 559-567.

Kuppusamy, K. and S. Govindrajan, (1995). Hydrazinium cation as a ligand: Preparation and spectral, thermal and XRD studies on hydrazinium metal phthalates. Eur. J. Solid state Inorg. Chem. 32: 997-1005.

Kuppusamy, K. and S. Govindrajan, (1996). Benzoate complexes of di positive first row transition metal ions with hydrazine. Synth. React. Inorg. Met. Org. Chem. 26: 225-231.

Nicholls, D., M. Rowley and R. Swindells, (1996). Hydrazine complexes of Cobalt(II) chloride. $J$. Chem. Soc. 5: 950-953.

Ravindranathan, P. and K.C. Patil, (1983). Thermal reactivity of metal acetate hydrazinates. Thermochim. Acta. 71: 153-160.

Sivasankar, B.N. (2006). Cobalt(II), Nickel(II) and Zinc(II) dicarboxylate complexes with hydrazine as bridged ligand characterization and thermal degradation. J. Therm. Anal. Calorim. 86: 385-392

Sivasankar, B.N. and S. Govindrajan, (1994b). BisHydrazine metal maleates and fumarates: Preparation, spectral and thermal studies. $Z$. Naturforsch. 49: 950-956.

Sivasankar, B.N. and S. Govindrajan, (1994a). Studies on bis(hydrazine) metal malonates and succinates. Synth. React. Inorg. Met. Org. Chem. 24: 1573-1580.

Sivasankar, B.N. and S. Govindrajan, (1995a). Formato complexes of Cobalt(II), Nickel(II) and Zinc(II) with the hydrazinium(1+) Cation. Synth. React. Inorg. Met. Org. Chem. 25: 31-37.

Sivasankar, B.N. and S. Govindrajan, (1995b). Trishydrazine metal glycinates and glycolates: Preparation, spectral and thermal studies. Thermochim. Acta. 244: 235-242.

Sivasankar, B.N. and S. Govindrajan, (1996). Hydrazine mixed metal malonates-New preursors for metal cobaltites. Mater. Res. Bull. 31: 47-53.

Sivasankar, B.N. and S. Govindrajan, (1997). Actate and malonate complexes of Cobalt(II), Nickel(II) and Zinc(II) with hydrazinium cation. J. Therm. Anal. 48: 1401-1408.

Vikram, L. and B.N. Sivasankar, (2007). Spectral, thermal and X-ray studies on some new bishydrazine metal glyoxylates and bis- hydrazine mixed metal glyoxylates, Thermochim. Acta. 452: 20-28.

Von Burg, R. and T. Stout, (1991). Toxicology Update: Hydrazine. J. Appl. Toxicol. 11: 447-456.

Yasodhai, S. and S. Govindrajan, (2000). Hydrazinium oxydiacetates and oxydiacetatedianion complexes of some divalent metals with hydrazine. Synth. React. Inorg. Met. Org. Chem. 30: 745-752. 